\title{
MEMBANGUN KEMITRAAN GEREJA DALAM PELAYANAN MISI MASA KINI
}

\author{
Leonard A.P. Hutapea
}

\section{PENDAHULUAN}

"Yesus mendekati mereka dan berkata: "Kepada-Ku telah diberkan kuasa di surga dan di bumi. Karena itu pergilah, jadikanlah semua bangsa murid-Ku dan baptislah mereka dalam nama Bapa dan Anak dan Roh Kudus, dan ajarlah mereka melakukan segala sesuatu yang telah Kuperintahkan kepadamu. Dan ketahuilah, Aku menyertai kamu senantiasa sampai kepada akhir zaman"

(Matius 28:18-20)

Firman Tuhan di atas dikenal sebagai Amanat Agung Tuhan Yesus ketika menampakkan diri kepada sebelas orang murid-Nya yang terjadi di Galilea, di sinilah Tuhan Yesus menyampaikan kata-kata terakhir-Nya kepada para murid. Dalam pertemuan terakhir ini setidaknya Yesus melakukan tiga hal penting yang perlu kita perhatikan: pertama, Ia meyakinkan mereka akan kuasa-Nya. Kedua, Ia memberi mereka suatu tugas. Ketiga, Ia menjanjikan mereka akan kehadiran-Nya. ${ }^{1}$

Banyak orang Kristen berpendapat bahwa Amanat Agung Yesus sudah cukup dilaksanakan dan bila Allah bermaksud dalam menyelamatkan orangorang kafir, maka Ia dapat menggunakan cara untuk membawa mereka kepada Injil atau Injil kepada mereka. ${ }^{2}$ Pandangan-pandangan seperti itulah yang pada akhirnya membuat orang-orang Kristen tidak melakukan tugas penginjilan dengan baik dan cenderung menghindarinya bahkan timbul pola pikir bahwa tugas penginjilan hanyalah tugas gembala-gembala jemaat, orang-orang yang pernah belajar Theologi, majelis gereja, aktivis gereja dan lain sebagainya.

\footnotetext{
${ }^{1}$ W.Barclay, Pemahaman Alkitab Setiap Hari Matius Psl 11-28 (Jakarta: BPK Gunung Mulia, 2009), 598

${ }^{2}$ Norman E.Thomas, Teks-teks Klasik tentang Misi dan Kekristenan Sedunia (Jakarta: BPK Gunung Mulia, 2001), 81
} 


\section{PENGERTIAN GEREJA DAN MISI}

\section{A. Pengertian Gereja}

Pengertian gereja secara Alkitabiah dapat dilihat dalam Perjanjian Lama dan Perjanjian Baru:

\section{Perjanjian Lama}

Ada dua istilah untuk menunjuk Gereja. Pertama, Qahal (kahal) yang berarti memanggil, kata ini menunjuk arti yang sesungguhnya dari pertemuan bersama suatu umat. Kata Qahal sering kita jumpai dalam Tawarikh, Ezra dan Nehemia. Kedua, Edhah yang berarti memilih atau menunjuk atau bertemu bersama-sama di suatu tempat yang disepakati. Apabila kata ini diterapkan pada bangsa Israel maka kata itu menunjuk pada masyarakat bangsa itu sendiri yang dibentuk oleh anak-anak Israel atau kepala perwakilan mereka, bergabung bersama maupun tidak. Kata Edhah sering dipakai dalam kitab Keluaran, Imamat, Bilangan dan Yosua. Kata Qahal dan Edhah sering digunakan tanpa membedakan arti. Kedua kata tersebut seringkali digabung menjadi kumpulan jemaah dapat dilihat dalam Kel 12:6; Bil 14:5; Yer 26:17. Selanjutnya kata Sunagoge merupakan terjemahan yang paling umum dipakai dalam Septuaginta untuk Edhah dan juga untuk menterjemahkan kata Qahal yang dipakai dalam kitab Musa (Pentateuch). Jadi istilah Edheh dan Qahal tersebut kemudian digunakan untuk menyebut umat Allah. ${ }^{3}$

\section{Perjanjian Baru}

Ada tiga kata dalam Perjanjian Baru yang menjelaskan tentang gereja. Pertama, kata evkklhsi, a (ekklesia) berasal dari kata evk (ek) dan k, a levw (kaleo) yang artinya memanggil ke luar. ${ }^{4}$ Tuhan Yesus pertama

\footnotetext{
${ }^{3}$ Louis Berkhof, Teologi Sistematika “Doktrin Gereja” (Jakarta: Lembaga Reformed Injili Indonesia, 2008), 5-6.

${ }^{4}$ Ibid., 6
} 
kali menggunakan kata evkklhsi, an (Mat 16:18). Pengertian secara umum dari evkklhsi, an yaitu:

a. Sekumpulan orang percaya di dalam tempat tertentu.

b. Sekumpulan orang percaya di suatu rumah (ekklesia Domestik) (Rom 16:23; I Kor 16:19; Kol 4:15).

c. Perkumpulan tubuh Kristus di seluruh dunia (I Kor 10:32, 11:22, 12:28).

d. Perkumpulan seluruh orang percaya (Am), baik yang hidup maupun yang sudah mati (di dunia dan di surga).

Kedua, kata sunagwgh, (sunagoge), berasal dari kata sun (sun) dan agw (ago) yang berarti datang atau berkumpul bersama. Kata sunagwgh, sendiri menunjuk kepada pertemuan ibadah orang Yahudi atau menunjuk kepada bangunan tempat mereka berkumpul untuk beribadah secara umum. Ketiga, kata Kuriake terjemahan Church (Inggris), Kerk (Belanda), Kirche (Jerman) memang kata-kata ini tidak berasal dari kata ekklesia, kata Kuriake berarti milik Tuhan (Mat 4:23; KPR 13:43; Why 2:9; 3:9). Kata ini sendiri sangat menekankan kenyataan bahwa gereja adalah milik Tuhan. Istilah yang sering muncul to kuriakon atau he kuriake pada awalnya menunjukkan tempat gereja berkumpul, dimengerti sebagai milik Tuhan (to kuriakon), dipahami sebagai tempat yang berisi orang percaya berkumpul untuk beribadah, tidak kosong. Maka terjemahan yang tepat adalah sebagai bangunan rohani dari Allah. ${ }^{5}$

Pada masa berikutnya sebagai hasil perluasan gereja, kata (ekklesia) mendapat pemakaian yang lebih luas. Berkhof mengemukakan lima pemakaian kata dari gereja yang penting untuk diperhatikan:

a. Kata ekklesia menunjuk kepada arti sekumpulan orang percaya di dalam suatu tempat yang sama yaitu gereja lokal tanpa memperhatikan apakah orang percaya datang dengan maksud beribadah atau tidak (KPR 5:11, 11:26, Rom 16:4, I Kor 16:1).

${ }^{5}$ Ibid., 9 
b. Ekklesia domestik, yaitu gereja dalam rumah pribadi seseorang, sebuah ruangan yang besar yang disediakan untuk beribadah (Rom 16:23, I Kor 16:19).

c. Menunjuk kepada sekelompok gereja-gereja yang ada di Yudea, Galilea dan Samaria (KPR 9:31).

d. Keseluruhan tubuh Kristus di dunia, yaitu kesatuan dari orangorang yang beribadah kepada Kristus dan berkumpul di bawah pimpinan pejabat-pejabat yang telah dipilih.

e. Keseluruhan tubuh orang-orang beriman, baik di bumi maupun di surga, yang telah atau yang akan dipersatukan secara spiritual dengan Kristus sebagai Juruselamat.

Dengan demikian dapat disimpulkan bahwa gereja adalah kumpulan orang-orang yang dipanggil keluar dari kegelapan menuju terang-Nya yaitu persekutuan dengan orang-orang beriman dalam Kristus. Gereja bukan berarti gedungnya saja melainkan termasuk orang-orang yang ada di dalamnya.

\section{B. Pengertian Misi}

Istilah misi (mission) berasal dari bahasa Latin "mission" yang diangkat dari kata dasar "mittere" yang berkaitan dengan kata "missum" yang artinya "to send" (mengirim/mengutus). Padanan dari kata ini dalam bahasa Yunani adalah avpo, stevvllw (apostello). ${ }^{6}$ Menurut Tomatala bahwa istilah mission menunjuk pada misi Allah (mission Dei) sedangkan missions ada tugas dari misi Allah itu (yang dipercayakan oleh Allah kepada umat-Nya) ${ }^{7}$

Sedangkan menurut Kamus Besar Bahasa Indonesia (KBBI): 1. Misi adalah kegiatan menyebarkan kabar gembira (Injil) dan mendirikan jemaatjemaat setempat yang dilakukan atas dasar pengutusan sebagai kelanjutan misi Kristus. 2. Misi adalah tugas yang dirasakan orang sebagai suatu kewajiban untuk melakukannya demi agama, ideologi, patriotisme dan sebagainya. ${ }^{8}$ Selanjutnya hal terpenting adalah mempertahankan pengertian yang Alkitabiah, jelas, fokus, yang tepat sesuai apa yang dilakukan gereja. Misi

\footnotetext{
${ }^{6}$ Barclay M.Newman Jr, Kamus Yunani-Indonesia (Jakarta: BPK Gunung Mulia, 2006), 20

${ }^{7}$ Yakub Tomatala, Teologi Misi (Jakarta: YT Leadership Foundation, 2003), 19

${ }^{8}$ Lukman Ali, Kamus Besar Bahasa Indonesia (Jakarta: Balai Pustaka, 1999), 460
} 
juga merupakan segala sesuatu yang dikerjakan gereja; Pergi ke negeri asing; Pengumuman secara politis-negara lain; Sesuatu yang orang kerjakan untuk yang membutuhkan; Penginjilan; Pendidikan; Pengembangan Sosial-Ekonomi; Bantuan antar gereja; Pemasyarakatan; Pembudayaan; Penanaman Gereja. Dalam pelaksanaan Amanat Agung, jemaat harus bergantung kepada Roh Kudus dan Firman Tuhan agar taat kepada Allah dan mampu mengkomunikasikan Injil kepada semua manusia.

Dalam hubungannya dengan Kerajaan Allah, Gereja dan Dunia, misi adalah suatu pelayanan yang menyeberangi batas-batas budaya melalui proklamasi berita dan perbuatan kedatangan Kerajaan Allah dalam Yesus Kristus melalui partisipasi gereja dalam misi Allah mendamaikan manusia dengan Allah dengan diri mereka sendiri dengan sesama dan dengan dunia serta mengumpulkan mereka dalam persekutuan gereja melalui pertobatan dan iman dalam Yesus Kristus oleh pekerjaan Roh Kudus dengan target transformasi dunia sebagai tanda dari Kerajaan Allah dalam Yesus Kristus.

Pelayanan misi merupakan tanggungjawab semua orang yang telah percaya kepada Yesus Kristus. Ketika seseorang memperoleh keselamatan maka pada waktu yang bersamaan dia juga menerima suatu tugas yang baru yaitu melakukan amanat untuk memberitakan Injil. Dalam hal ini Packer berpandangan bahwa:

Kita semua (komunitas Kristen) mengemban amanat untuk membaktikan diri memberitakan kabar baik dan untuk memakai semua kemampuan kita untuk membuat Injil menjadi perhatian dunia. ${ }^{9}$

Misi dimulai dari Allah, oleh Allah dan demi kemuliaan Allah sendiri. Hal serupa dikatakan oleh Fernando bahwa Allah adalah sumber, asal-usul misi. Misi dapat dikatakan sebagai pelaksana maksud-maksud Allah untuk menggenapi tujuan-Nya di dunia ini. Tuhan Yesus mengorbankan dirinya demi keselamatan umat manusia, hal ini merupakan pesan dan teladan bagi misi, semua misionaris ataupun semua orang percaya. ${ }^{10}$ Semua orang percaya harus berpegang teguh pada Amanat Agung Tuhan Yesus dan harus semangat

9 J.I.Packer, Pengijilan dan Kedaulatan Allah (Surabaya: Momentum, 2009), 17

${ }^{10}$ Ajith Fernando., Allah Tritunggal dan Misi (Jakarta: Yayasan Komunikasi Bina Kasih, 2008), 7 
dalam memberitakan Injil dengan satu keyakinan bahwa Allah Tritunggal sendiri yang selalu menyertai.

\section{TUJUAN GEREJA}

Setiap institut yang didirikan pasti memiliki tujuan yang jelas, tidak ada orang yang mendirikan sesuatu tanpa ada tujuan yang jelas. Demikian juga dengan gereja yang Allah dirikan dimana tujuan utama kehadiran gereja jelas dalam Amanat Agung. Amanat Agung berisikan kehendak Allah bagi gerejaNya. ${ }^{11}$ Gereja merupakan tubuh dan Kristus adalah Kepalanya (Ef 4:1-16), tubuh merupakan satu kesatuan antara bagian yang satu dengan bagian yang lainnya.

Sebagai satu tubuh tidak ada satu bagian pun yang diabaikan dan dianggap kurang penting. Sebagai tubuh Kristus hal ini menunjukkan betapa eratnya ikatan yang mempersatukan semua orang percaya dalam mengembangkan karunia-karunia rohaninya yang berbeda untuk membangun tubuh Kristus dalam hubungan Kristus sebagai Kepala mengacu kepada dua kebenaran. Pertama, jemaat ialah sarana bagi Kristus dalam menjalankan misiNya. Kedua, jemaat sebagai tubuh Kristus mempunyai banyak anggota dan setiap anggota mempunyai karunia Roh. ${ }^{12}$

Jadi dalam hal ini sebagai tubuh Kristus, gereja harus bersatu padu dalam menjalankan kehendak Allah bagi gereja-Nya. Karena itu kehidupan orangorang Kristen harus menjadi berkat dan harus berbeda dari orang-orang yang tidak mengenal Kristus. Jika kehidupan orang-orang Kristen memancarkan Kristus, maka orang lain akan melihat dan pada akhirnya nama Allah dimuliakan karena orang-orang Kristen ialah duta Allah di dunia ini. ${ }^{13}$

\footnotetext{
${ }^{11}$ Suhento Liauw, Doktrin Gereja Alkitabiah, (Jakarta: Gereja Baptis Independen Alkitabiah AGAPHE, 1996), 57

12 Theodore Willians, Misi dan Jemaat Lokal (Jakarta:OMF), 5.

${ }^{13}$ Norman E. Thomas, Teks-Teks Klasik Tentang Misi dan Kekristenan Sedunia, (Jakarta: Gunung Mulia, 2001), 123.
} 


\section{TUGAS GEREJA}

Tugas pokok Gereja dan tanggungjawab gereja dengan jelas dapat dilihat dalam Amanat Agung Tuhan Yesus. Dalam Perjanjian Baru ada 5 bagian Firman Tuhan yang berbicara tentang perintah Agung Tuhan Yesus.

1. Matius 28:18-20

2. Markus 16:15-18

3. Lukas 24:11-49

4. Yohanes 20:19-23

5. Kisah Para Rasul 1:6-8

Ayat-ayat di atas mengajarkan bahwa dalam perintah agung dari Tuhan Yesus terdapat wewenang, perintah dan janji. Perintah ini menuntut ketaatan kepada Tuhan, ada tugas utama yaitu menjadikan murid. Tugas inti ini didukung dengan mengajar untuk taat dan membaptis tiap orang yang diselamatkan Tuhan dari segala bangsa. Ada suatu jaminan yang pasti dari perintah agung ini dan isi jaminan itu ialah penyertaan Tuhan Yesus. Apabila Tuhan menyertai, Ia sendiri menjamin bahwa tugas penginjilan akan berhasil. ${ }^{14}$ Amanat Agung masih mengikat gereja-gereja pada masa kini, amanat ini tidak hanya diberikan oleh Tuhan Yesus kepada para rasul pada waktu itu untuk pelayanan mereka, tetapi diberikan juga kepada gereja untuk pelayanan sepanjang zaman. ${ }^{15}$ Gereja tidak hidup untuk dirinya sendiri, gereja sebagai umat Allah ada dan didirikan oleh Allah untuk membawa kabar baik bagi orang-orang yang belum percaya. Gereja merupakan alat bagi Allah untuk menjadikan saksi di tengah-tengah dunia, memulihkan keutuhan itulah maksud penginjilan, dengan membawa kembali mereka yang terhilang ke tempatnya di dalam tata rumah tangga Allah. ${ }^{16}$

Belajar dari kehidupan jemaat mula-mula (Kis. 2:47) bahwa jemaat mula-mula menerima tanggungjawab pemberitaan Injil. Setiap orang percaya dalam gereja mula-mula terlibat aktif dalam memberitakan Injil di manapun mereka berada. Mereka menjadi saksi baik dalam kehidupan mereka di tengah-

\footnotetext{
14 Yakob Tomatala, Penginjilan, (Malang: Gandum Mas, 1998), 23-24.

15 John Piper, Jadikan Sekalian Bangsa Bersukacita, (Bandung: Literatur Baptis Indonesia, 2001), 227.

${ }^{16}$ Norman E. Thomas, Teks-Teks Klasik Tentang Misi Dunia ...,226
} 
tengah orang-orang yang tidak percaya maupun ketika mereka secara khusus pergi untuk memberitakan Injil.

Melalui pemahaman Amanat Agung Tuhan Yesus, setiap orang percaya akan memahami dengan baik tanggungjawab untuk memberitakan Injil. Dengan demikian setiap orang percaya tidak perlu diperintahkan lagi dalam melaksanakan Amanat Agung karena setiap orang-orang percaya harus menjadi saksi di manapun ia berada baik dalam melakukan tugas sehari-hari maupun dalam interaksi dengan orang-orang yang belum percaya. ${ }^{17}$

Pada waktu kita dipercayakan melakukan pelayanan di suatu gereja serta merencanakan program-program gereja maka hal penting yang menjadi perhatian utama yaitu bagaimana peran dari gereja sendiri bagi persekutuan jemaat serta lingkungan gereja tersebut berkaitan dengan misi gereja sesuai mandat Alkitabiah?

\section{A. Memuliahkan Allah}

Tujuan utama hidup manusia ialah memuliakan Allah. Hal ini sama benarnya bagi orang percaya secara pribadi maupun bagi gereja secara keseluruhan. Alkitab berkali-kali menunjukkan hal ini sebagai maksud utama gereja (Rom 15:6,9; Ef 1:5-6,12,14,18; 3:21; II Tes 1:12; I Petrus 4:11). Tugas ini begitu mendasar sehingga bila dilaksanakan dengan setia maka tugas-tugas gereja yang lain dengan sendirinya juga akan terlaksana. Bagaimanakah Allah dimuliakan lewat gereja? (1) Kita memuliakan Allah dengan menyembah Dia (Yoh 4:23,24; band Filp 3:3; Why 22:9). (2) Kita memuliakan Allah dengan doa dan puji-pujian. Pemazmur mengatakan, "siapa yang mempersembahkan syukur sebagai korban, ia memuliakan Aku" (Maz 50:23). (3) Selanjutnya, kita juga memuliakan Dia dengan menjalani kehidupan yang saleh. Yesus mengatakan,"Dalam hal inilah Bapa-Ku dipermuliakan, yaitu jika kamu berbuat banyak dan dengan demikian kamu adalah murid-murid-Ku" (Yoh 15:8). Petrus menyatakan bahwa kita harus "memberitakan perbuatan-perbuatan yang besar dari Dia, yang telah memanggil [kita] dari kegelapan kepada terang-Nya yang ajaib" (I Pet 2:9; band. Titus 2:10).

${ }^{17}$ Caprili Guanga, Aku dan Gereja (Malang: Seminari Alkitab Asia Tenggara,1997), 69 


\section{B. Sebagai Gereja Yang Bertumbuh}

Rasul Paulus mengatakan bahwa Allah memberikan kepada gereja rasulrasul, nabi-nabi, pemberita-pemberita Injil, gembala-gembala dan pengajarpengajar "untuk memperlengkapi orang-orang kudus bagi pekerjaan pelayanan, bagi pembangunan tubuh Kristus, sampai kita semua telah mencapai kesatuan iman...(Ef 4:12-16). Jelaslah, ini berarti indoktrinasi para anggota jemaat, supaya mereka dapat menjadi dewasa dan sanggup berdiri tegak menghadapi ajaran-ajaran sesat di sekitar mereka. Inilah yang dinamakan membangun tubuh Kristus (Kol 2:7). Kebaktian umum di gereja bertujuan melaksanakan hal ini (I Kor 14:26), namun setiap orang percaya juga harus membangun diri mereka sendiri dalam iman yang teramat kudus ini (Yudas 20) serta "bertumbuh dalam kasih karunia dan dalam pengenalan akan Tuhan dan Juruselamat kita, Yesus Kristus" (II Pet 3:18). Paulus menentang kita untuk memakai bahan-bahan yang baik dalam mendirikan bait rohani Allah (I Kor 3:10-15) dan memperingatkan kita agar tidak memakai bahan-bahan yang tidak baik. Maka jelaslah gereja harus mengindoktrinasi warganya, mengembangkan sikap-sikap baik kehidupan Kristen di dalam diri mereka serta mengajar mereka untuk bekerja sama satu dengan yang lain dalam pelayanan Kristus.

\section{Sebagai Gereja Yang Kudus}

Kristus mengurbankan diri-Nya untuk gereja "untuk menguduskannya, sesudah Ia menyucikannya dengan memandikannya dengan air dan Firman, supaya dengan demikian Ia menempatkan jemaat di hadapan diri-Nya dengan cemerlang tanpa cacat atau kerut atau yang serupa itu, tetapi supaya jemaat kudus dan tidak bercela" (Ef 5:26-27). Dalam hal ini ada penyucian yang dilakukan oleh Allah Bapa (Yoh 15:2), terutama dengan jalan menghukum kita (I Kor 11:32; Ibr 12:10). Ada juga penyucian yang harus dilaksanakan oleh orang percaya itu (I Kor 11:28-31; II Kor 7:1; I Yoh 3:2), tetapi ada juga bentuk penyucian yang harus dilakukan oleh gereja setempat (Mat 18:17). Kekudusan orang percaya disempurnakan melalui persekutuan dengan orang- 
orang lain, tidak pernah terlepas darinya. ${ }^{18}$ Gereja mula-mula memang memberikan teladan dalam pelaksanaan disiplin gereja, dan gereja masa kini tidak dibebaskan dari tugas melaksanakan disiplin gereja (KPR 5:11; Rom 16:17; I Kor 5:6-8, 13; II Tes 3:6, 14; Titus 3:10-11;). Berbagai perpecahan yang sering timbul, munculnya ajaran-ajaran sesat dan lain sebagainya dapat menjadi suatu alasan untuk memberlakukan disiplin. Disiplin dalam gereja tentu akan menolong gereja secara terus-menerus dalam mempersiapkan diri menyambut kedatangan-Nya (sebagai mempelai perempuan sesuai Wahyu 19:7).

\section{Sebagai Gereja Yang Dewasa (dalam pengajaran)}

Tuhan telah mengaruniakan kepada gereja-Nya yaitu rasul-rasul, nabinabi, pemberita-pemberita Injil, gembala-gembala dan pengajar-pengajar dengan tujuan "memperlengkapi orang-orang kudus bagi pekerjaan pelayanan" (Ef 4:12). Yesus juga telah memberikan Amanat Agung-Nya yang berisi perintah, bukan saja untuk menjadikan orang-orang sebagai murid dan membaptiskan mereka, tetapi setelah itu juga mengajarkan mereka untuk melakukan segala sesuatu yang telah diperintahkan-Nya (Mat 28:20). Dalam hal ini James Montgomery berpendapat:

Pekerjaan misi yang semestinya adalah pergi keluar dengan Injil, memenangkan manusia bagi Kristus, membawa mereka ke dalam persekutuan gereja, kemudian memastikan mereka diajari kebenarankebenaran yang tercatat di dalam kitab suci. ${ }^{19}$

Karena itulah tidak dapat disangkal lagi bahwa gereja harus menjalankan program pendidikan dan pelatihan bagi anggota jemaatnya secara keseluruhan. Gereja harus mengajarkan kebenaran-kebenaran Tuhan kepada jemaatnya serta secara rutin setia dalam mengajarkan ajaran para rasul. Paulus mengarahkan jemaat Filipi untuk memperhatikan semua jenis pengetahuan yang berharga. Paulus berkata, "jadi akhirnya, saudara-saudara, semua yang

${ }^{18}$ Bnd. Simon Chan, Spiritual Theology (Yogyakarta: ANDI, 2010), 135

${ }^{19}$ James Montgomery Boice, Dasar-dasar Iman Kristen (Surabaya: Momentum, 2011), 757 
benar, semua yang mulia, semua yang adil, semua yang suci, semua yang manis, semua yang sedap didengar, semua yang disebut kebajikan dan patut dipuji, pikirkanlah semuanya itu" (Filp 4:8; band. II Timotius 2:2)

\section{E. Sebagai Gereja Yang Bersaksi}

Dalam Amanat Agung jelas sekali mengenai penugasan gereja untuk pergi ke seluruh dunia serta menjadikan sekalian bangsa murid Tuhan (Mat 28:19; Luk 24:46-48; KPR 1:8). Alkitab tidak menyuruh gereja menobatkan dunia, melainkan untuk menginjili dunia, artinya gereja berhutang kepada seluruh dunia yaitu gereja bertanggung jawab untuk memberita kesempatan kepada dunia untuk mendengarkan Injil serta menerima Kristus. Gereja juga dikatakan sebagai saksi Kristus yang berarti gereja hadir untuk menyaksikan Kristus sehingga dapat membawa orang-orang kepada-Nya. ${ }^{20}$ Kita tahu bahwa tidak mungkin seluruh dunia akan menanggapi Injil, namun gereja berkewajiban memberi kesempatan kepada seluruh dunia untuk mengenal Kristus dan menerima keselamatan yang disediakan-Nya. Dewasa ini Tuhan sedang memanggil dari antara bangsa-bangsa non-Yahudi suatu umat bagi nama-Nya (KPR 15:14) dan tindakan tersebut dilakukan-Nya dengan perantaraan gereja dan Roh Kudus-Nya. Penginjilan dimulai dengan menyelidiki kebutuhan-kebutuhan yang ada (Yoh 4:28-38; band. Matius 9:3638). Maka dengan demikian jelaslah bahwa setiap gereja harus belajar dan melakukan misi. Sikap ini juga terungkap secara jelas dalam doa syafaat untuk pelayanan gereja (Mat 9:38), penyediaan dana untuk misi (Filp 4:1518), pengutusan para misionaris (KPR 13:1-3; 14:26; Rom 10:15) serta ikut terlibat di ladang-ladang misi (Rom 1:13-15; 15:20).

\section{F. Menjadi Garam dan Terang Dunia}

Tuhan Yesus mengatakan bahwa orang-orang percaya adalah garam dunia dan terang dunia (Mat 5:13-15). Adanya pengaruh dan kesaksian hidup yang baik maka orang-orang Kristen dapat menahan perkembangan

${ }^{20}$ Bnd. Sadikin Gunawan, Menjadi Orang Kristen Yang Berbeda (Jakarta: Pustaka Sorgawi, 2006), 85 
pelanggaran hukum (II Tes 2:6-7). Tuhan masih menahan penghukuman karena kehadiran orang-orang saleh di tengah-tengah orang fasik (Kej 18:2223). Dengan demikian diharapkan setiap orang percaya harus berani menyatakan tuntutan-tuntutan Tuhan yang adil dari manusia serta memberitahukan perlunya pertobatan dan kelahiran kembali bagi mereka yang belum percaya dan yang belum mendengar Injil. Untuk mencapai tujuan ini, Tuhan telah menjadikan umat-Nya pemelihara kebenaran Allah (II Kor 5:19; Gal 2:7; I Tim 1:11; 3:15). Dalam Alkitab, umat manusia senantiasa diharapkan menemukan kebenaran mengenai Allah serta hal-hal rohani. Akan tetapi lebih daripada itu, gereja juga bertugas penuh untuk menawarkan Firman kehidupan kepada dunia (Filp 2:16) dan berjuang untuk mempertahankan kebenaran itu (Yudas 3) karena memang dalam kenyataannya hanya sedikit sekali masyarakat dunia yang menyadari dan merasakan betapa untungnya mereka dengan adanya umat Allah di tengah-tengah mereka.

\section{G. Sebagai Gereja Yang Berpengaruh Bagi Lingkungan dan Dunia}

Sekalipun orang percaya harus memisahkan diri dari segala ikatanikatan duniawi (II Kor 6:14-18), ia tetap harus mendukung semua usaha yang jelas-jelas berusaha memajukan kesejahteraan sosial, ekonomi, politik dan pendidikan masyarakat luas. Paulus mengatakan, "karena itu, selama masih ada kesempatan bagi kita, marilah berbuat baik kepada semua orang, tetapi terutama kepada kawan-kawan kita seiman" (Gal 6:10). Dalam ayat ini jelas dimaksudkan adalah bahwa kita mempunyai tugas utama yaitu memperhatikan kesejahteraan kawan-kawan seiman, tetapi kita juga harus memperhatikan kesejahteraan sesama manusia lainnya. Alkitab tidak mendukung pandangan bahwa orang-orang Kristen tidak perlu menangani masalah-masalah sosial karena pandangan Kristen tentang manusia yang sudah ditebus mencakup pengakuan akan adanya kewajiban sosial dan memperbaiki lingkungan mereka. ${ }^{21}$ Apa yang dilakukan Tuhan Yesus merupakan teladan terbaik untuk diikuti. Tindakan-tindakan reformasi masyarakat, termasuk bantuan-bantuan sosial, harus selalu secara tegas datang kemudian dari tugas penginjilan. Orang Kristen harus menjadikan semua perbuatan amal dan kebajikannya suatu

${ }^{21}$ Donald Guthrie, Teologi Perjanjian Baru 3 (Jakarta: BPK Gunung Mulia, 1996), 
kesaksian bagi Kristus. Yesus mungkin saja telah memberi makan kepada lima ribu orang laki-laki sebagai tindakan berperikemanusiaan, tetapi tindakan tersebut pasti dilakukan-Nya terutama sebagai suatu kesaksian terhadap kuasa dan ke-Allahan-Nya sendiri. Dengan kata lain, orang Kristen harus menjadikan semua perbuatan baiknya itu sebagai sarana untuk bersaksi bagi Kristus.

Dari uraian di atas dapat disimpulkan bahwa segala sesuatu yang dilakukan gereja harus memiliki pengaruh yang positif baik bagi persekutuan orang percaya di dalamnya maupun masyarakat di sekitarnya yang tentu harus merasakan dampak kehadiran gereja.

Selain itu gereja sebagai komunitas orang percaya yang memiliki dampak bagi lingkungannya maka gereja juga harus segera berperan aktif untuk membangun kemitraan nyata dalam pelayanan misi sebagai perwujudan dari gereja yang hidup yang setia dalam menjalankan Amanat Agung Tuhan Yesus Kristus karena telah disadari gereja tidak dapat bergerak dan berjalan sendiri-sendiri dalam memajukan program-program dan pelayanan gereja.

\section{KEMITRAAN GEREJA DALAM PELAYANAN MISI}

Allah yang berdaulat dan berkuasa sangat mempercayai gereja-Nya dalam melaksanakan misi. Hal ini dimulai dari Yerusalem, Yudea, Samaria sampai ujung bumi (KPR 1:8). Orang percaya atau kelompok gereja tertentu tidaklah mungkin dapat melaksanakannya secara sendiri-sendiri, namun hal ini perlu dikerjakan secara bersama-sama agar terlaksana dengan baik dan efektif. Dalam hal inilah suatu kemitraan sangat diperlukan guna mendukung pelayanan-pelayanan misi yang direncanakan baik oleh gereja-gereja lokal, sekolah-sekolah Theologia serta lembaga-lembaga misi lainnya. Memulai dan membangun kerja sama ini memang merupakan tantangan yang cukup besar dan menantang terutama dalam membuat struktur-struktur misi skala nasional yang saling bergandengan tangan. Namun tidak dapat dihindari pada dasarnya gereja memang memerlukan struktur yang saling berhubungan tersebut untuk menyatakan kesatuan dalam pelayanan misi yang akan melampaui semua batas manusia dan budaya. 


\section{A. Kemitraan dalam Misi - Sebagai Karakter Komunitas Alkitabiah}

Pada dasarnya kemitraan dalam misi bukanlah sesuatu yang baru, namun telah diterapkan sejak Allah sendiri merencanakan keselamatan bagi dunia ini, di mana dalam ke-Tritunggalan-Nya Ia bersama-sama melaksanakan karya penyelamatan bagi dunia ini. Hal itu dapat kita perhatikan melalui surat Paulus kepada Jemaat di Efesus pasal 1:

1) Allah Bapa dalam Kristus telah mengaruniakan segala berkat rohani di dalam surga (ay 3).

2) Yesus Kristus melakukan pengampunan dosa di kayu salib (ay 7).

3) Roh Kudus memeteraikan orang percaya, sebagai jaminan bagiannya sampai keselamatan kekal yang dijanjikan-Nya utuh serta dinyatakan sepenuhnya (ay 13-14).

Allah Tritunggal melaksanakan kemitraan yang indah dan sempurna bagi terwujudnya gereja Tuhan di bumi ini dan dengan demikian komunitas Ilahi menjadi model kemitraan, pelayanan dan pengutusan yang tepat demi keselamatan dunia ( bnd Yoh 20:21). Melalui penyertaan serta pimpinan Roh Kudus hal tersebut dikerjakan dan dilaksanakan oleh gereja mula-mula dalam Perjanjian Baru (Kis 13). Roh Kudus mengarahkan Gereja di Antiokhia untuk memisahkan dan mengutus Paulus dan Barnabas menyelesaikan pekerjaan misi tersebut, dan mereka menyampaikan hasilnya kepada jemaat bahwa Injil sudah tersebar sampai kepada bangsa-bangsa lain (KPR 14:26-27). Dalam hal inilah kita memperhatikan adanya kemitraan yang kuat antara Roh Kudus, Gereja dan misionaris yang diutus.

Pada kenyataannya kerjasama pada kemitraan ini berlangsung dari waktu ke waktu dalam pelayanan Paulus dengan jemaat-jemaat lainnya, misalnya Jemaat Filipi. Paulus mengungkapkan bagaimana persekutuan mereka melalui Berita Injil mulai dari hari pertama sampai sekarang ini (Filp 1:5), begitu juga Euodia dan Sintikhe berjuang dengan Paulus untuk pekabaran Injil (Filp 4:2). Setelah mereka mendengar Injil dan dibina oleh Paulus, jemaat Filipi menunjukkan dukungannya kepada Paulus dalam pekabaran Injil ke tempattempat lain, baik dengan mengirimkan bantuan kepadanya maupun dengan mengutus Epafroditus untuk melayani kebutuhannya (Filp 2:25; 4:15-18), sehingga Injil dapat terus tersebar hingga ke tempat yang lebih jauh 
menjangkau banyak orang menjadi percaya kepada Kristus. Pada bagian ini Kirk menegaskan:

"Kemitraan dalam misi menjadi bagian dari hakikat Gereja: yaitu kemitraan bukanlah terutama apa yang Gereja lakukan, melainkan apa yang menjadi sifatnya. Gereja-gereja (secara teologis) terikat satu sama lain, sebab Allah telah memanggil masing-masing "kepada persekutuan dengan Anak-Nya Yesus Kristus, Tuhan kita" (I Kor 1:9). Karena itu kemitraan bukanlah suatu slogan bagus yang diciptakan oleh suatu panitia yang pintar; ia merupakan pernyataan dari suatu kehidupan yang adalah satu, tidak dapat dibagi-bagi dan dimiliki bersama dalam Yesus Kristus."22

Lewat pengamatan kita melalui sejarah gereja nampak terjadinya degradasi di dalam pertumbuhan gereja sendiri karena gereja-gereja yang ada cenderung berpusat hanya ke dalam dan tidak menjalankan panggilannya secara utuh. Pelayanan pekabaran Injil tidak lagi menjadi proyek pelayanan bersama, namun hanya dikerjakan oleh individu-individu yang terbeban. Hal inilah yang menyebabkan adanya lembaga misi mendorong warga jemaat yang memiliki beban-beban misi dalam dirinya masing-masing untuk kembali mendorong gereja agar melakukan dan melaksanakan kegiatan pengutusan, walaupun hal ini sering disalahmengertikan oleh gereja yang berpikir bahwa lembaga misi hanya ingin mendapat dukungan dana agar pelayanan misinya berkembang. Dalam kenyataannya kehadiran lembaga misi diizinkan Tuhan untuk melaksanakan misi Allah serta mendorong gereja agar kembali menggumuli panggilannya agar menjalankan Amanat Agung dari pemilik Gereja yaitu Tuhan Yesus Kristus sendiri.

\section{B. Dasar dan Tujuan Suatu Kemitraan Dalam Misi Saat Ini}

Dengan berkembangan dunia modern dan gerakan misi sedunia masa kini akan mendorong kita untuk bermitra dalam misi. Dampak dari era globalisasi ini adalah berkembangnya kemitraan di antara orang-orang Kristen

${ }^{22}$ Andrew Kirk, What is Mission?, (London: Darton, Longman, Todd, 1999), 187. 
di Barat dan Selatan / Timur serta munculnya kerja sama antara gereja-gereja lokal dan agen-agen misi, dan di sinilah misi dikatakan multi-arah.

Adapun tujuan umum dari kemitraan dalam misi sendiri ialah: memaksimalkan misi global yang dapat memberikan pengaruh bagi Kerajaan Allah. Dalam rangka mencapai tujuan tersebut maka ada beberapa alasan umat Allah perlu bekerja sama, sekaligus merupakan tujuan tertentu yang perlu dicapai, antara lain:

1) Kerinduan untuk saling mengasihi melalui kerjasama dan saling mendukung, supaya dunia percaya kepada-Nya (bnd Yoh 13:35).

2) Mengajak seluruh gereja Tuhan terlibat secara nasional dan internasional untuk memenuhi panggilannya dan melaksanakan Amanat Tuhan.

3) Melakukan kerjasama untuk menjangkau suku atau golongan atau kelompok yang belum terjangkau secara lebih efektif.

4) Agar sedia membagikan sumber yang dikaruniakan Allah (bersinergi).

5) Agar bersedia membagikan kemampuan dan keterampilan dalam spesialisasi bidang yang berbeda seperti penginjilan, pelayanan sosial, pelayanan lintas budaya dan lain sebagainya.

6) Tidak menghambur-hamburkan sumber-sumber yang ada dan menghindari kompetisi serta mengulangi hal yang sama.

7) Agar belajar satu dengan yang lain dan saling menguatkan dalam menghadapi penderitaan. ${ }^{23}$

\section{Kemitraan Pelayanan Misi Lintas Budaya Dalam Konteks Dunia Modern}

"Terlalu sedikit bagimu hanya untuk menjadi hamba-Ku, untuk menegakkan suku-suku Yakub dan untuk mengembalikan orang-orang Israel yang masih terpelihara. Tetapi Aku akan membuat engkau menjadi terang bagi bangsa-bangsa supaya keselamatan daripada-Ku sampai ke ujung bumi” (Yes 49:6).

${ }^{23}$ Kirk, What is Mission?.., 190-191 
Sesuai dasar Firman Tuhan di atas nyatalah bahwa Tuhan memang mengasihi bangsa Israel dan memilih mereka menjadi bangsa pertama yang mengenal dan mengalami kasih Tuhan yang menyelamatkan; namun Tuhan tidak hanya mengasihi bangsa Israel, Ia ingin memakai Israel yang sudah diselamatkan itu sebagai perpanjangan tangan-Nya untuk menjangkau bangsabangsa lain, segala bangsa di muka bumi. Selain itu visi Allah bagi dunia juga disingkapkan kepada Yohanes: "setelah itu aku melihat: sesungguhnya, suatu kumpulan besar orang banyak yang tidak dapat dihitung jumlahnya, dari segala bangsa dan suku dan umat dan bahasa, berdiri di hadapan tahta dan di hadapan Anak Domba, memakai jubah putih dan memegang daun-daun palem di tangan mereka" (Why 7:9).

Dari pernyataan di atas memperjelas bagi kita bahwa Ia ingin terus memakai gereja-Nya untuk mengasihi manusia yang terhilang yaitu dengan memberitakan Injil keselamatan kepada semua yang mau mendengar, supaya semuanya juga mendapat kesempatan untuk mengenal kasih Kristus dan percaya kepada-Nya, sehingga memperoleh hidup kekal (Yoh 3:16).

Namun tugas menjangkau semua suku bangsa yang teramat luas ini sangat membutuhkan pelayanan lintas budaya dan lintas golongan sosial. karena itulah orang-orang percaya perlu sekali bekerja sama dalam melaksanakan dan menyelesaikan Amanat Agung Tuhan dengan mengerahkan segala kemampuan, fasilitas dan talenta yang telah dimiliki. Dalam hal ini juga perlu menggalang kerjasama dengan sekolah Theologia karena sangat memperlengkapi para pekerja dan utusan Injil dengan pengertian dan keterampilan di bidang biblika tentang seluruh misi Tuhan di dunia, pemahaman kebudayaan/antropologi, kontekstualisasi, penginjilan, perintisan jemaat, pemuridan, sejarah gereja/misi dan lain sebagainya. Membangun kerjasama dengan lembaga misi yang mempunyai pengalaman di daerah geografis tertentu atau golongan tertentu akan sangat dibutuhkan, selain itu perlu segera dipikirkan keterlibatan jemaat untuk mendukung proyek misi sebagai contoh: jemaat mendukung satu proyek atau satu tenaga dari beberapa jemaat untuk satu proyek atau satu tenaga yang ada dan disiapkan untuk diutus ke luar negeri.

Di era globalisai, teknologi dan informasi ini sangat diperlukan, juga perlengkapan, pengertian dan pengetahuan teknis untuk menghadapi segala 
macam arus global serta memanfaatkan dengan baik potensi dari segala fasilitas agar dapat berkomunikasi dan membentuk jejaring secara efektif dan efisien. Maka untuk itulah perlu kerjasama dengan badan-badan atau tenagatenaga spesialis, dan adanya kebutuhan-kebutuhan ini bukan lagi sekedar tambahan atau alternatif melainkan sesuatu yang harus disiapkan dan dikerjakan segera.

Dalam konteks Indonesia, sebagaimana diketahui berjumlah penduduk besar dan beranekaragam di mana masih banyak sekali orang yang belum pernah mendapat kesempatan mendengar Kabar Baik tentang Kristus. Sementara di sisi lain gereja Indonesia pun cukup besar dan tersebar di seluruh kepulauan Indonesia, namun tidak merata, sehingga sangat perlu diadakan kerjasama dalam berbagai bentuk kemitraan dan jejaring untuk memaksimalkan pelayanan Kabar Baik untuk sampai ke kota dan desa. Hal ini tidak hanya menyangkut proyek dan pengutusan tenaga "penuh waktu", tetapi juga misalnya terkait penempatan tenaga "profesional" sesuai dengan bidangnya (dokter atau perawat, insinyur, guru, dst) yang memiliki kesadaran serta keterbebanan untuk menjadi alat Tuhan yang membawa damai dan pemulihan dan Kabar Baik di lokasi tertentu. Maka adanya tenaga seperti itu perlu didukung, disiapkan dan didoakan seperti halnya tenaga "penuh waktu."

\section{Pelaksanaan Kemitraan Pelayanan Misi}

Dalam memikirkan, merencanakan dan melakukan kemitraan pelayanan misi terlebih dahulu kita dapat memperhatikan bagaimana pandangan Luis Bush menyangkut kemitraan dalam segi-segi praktisnya:

"suatu asosiasi (hubungan kerja sama) yang terdiri atas dua atau lebih badan mandiri yang telah membentuk suatu hubungan saling mempercayai, serta telah menyepakati tujuan yang diharapkan dicapai bersama melalui membagikan kekuatan-kekuatan dan sumber-sumber mereka agar saling menguatkan" 
Perlu disadari juga dalam membentuk hubungan kerjasama yang demikian seringkali harus menghadapi berbagai macam hambatan yang perlu diatasi bersama-sama.

\section{E. Menghadapi Beberapa Masalah atau Tantangan Yang Timbul}

Adanya pertumbuhan dan perluasan dari gereja-gereja sedunia telah membangun suatu momentum pertumbuhan secara lebih kompleks di mana dalam bagian ini kerjasama yang semakin erat di tiap level menjadi sangat penting. Misi tidak lagi merupakan gerakan dari Barat tetapi global, dan adanya potensi pertentangan-pertentangan juga hubungan-hubungan yang terputus semakin besar. ${ }^{24}$ Selanjutnya Johnson dan Mandryk mengatakan banyak gereja, agen misi dan sekolah teologia "berjalan sendiri" dalam memenuhi Amanat Agung sehingga menghancurkan tubuh Kristus secara luas. Di sinilah penting sekali kita perhatikan motivasi untuk membangun kerjasama dalam pelayanan agar tidak ada kelompok tertentu yang terisolasi sehingga berdampak kepada pelayanan mereka.

Berikut ini beberapa hambatan yang muncul dalam pelayananan antara lain:

1) Apabila kita tidak memiliki suatu catatan program / agenda yang sama (visi dalam melakukannya untuk Kerajaan Allah).

2) Apabila kita selalu berpikir bahwa lembaga misi / gereja kita mempunyai keahlian atau pengertian yang lebih baik dari mitra-mitra pelayanan lainnya.

3) Jika suatu pihak ingin mengendalikan atau mempergunakan pihak lain, contoh melalui keuangan yang disalurkan, akibatnya hubungan menjadi tidak seimbang.

4) Apabila tidak membangun suatu hubungan kerjasama / relasi yang erat dan teratur.

\section{F. Langkah Membangun Kerjasama Praktis Untuk Kemitraan}

\footnotetext{
${ }^{24}$ Patrick Johnstone \& Jason Mandryk, WEC International, Operation World, (Carlisle: Paternoster, 2001), 711
} 
Sebagai suatu gerakan atau aksi nyata untuk mengatasi masalah dan hambatan yang ada, suatu kemitraan antara gereja dan lembaga-lembaga pelayanan misi perlu dibentuk dengan sangat hati-hati dan penuh hikmat, sambil mengutamakan pimpinan Tuhan dan memperhatikan banyak rencanarencana praktis. Suatu kerjasama dalam kemitraan merupakan kemampuan dalam melipatgandakan kemampuan dari masing-masing untuk memproduksi hasil, di mana jika dikerjakan sendiri-sendiri tidak dapat dicapai. Kerjasama tentu menciptakan rasa memiliki bersama yang terus-menerus, sehingga memungkinkan kegiatan-kegiatan yang saling bergantung dan menghasilkan multiplikasi dari hasil yang ada. ${ }^{25}$

Suatu kemitraan selanjutnya memang bukan hanya membangun komunikasi, melainkan membangun orang yang bermitra; belajar bersama sebagai suatu mitra dan menguatkan satu kepada yang lainnya dalam pimpinan Roh Kudus. Pada bagian inilah jejaring yang baik dalam membangun suatu kemitraan (gereja dan pelayanan misi) bisa terjadi jika ada beberapa faktor:

1) Kemitraan yang ada saling membutuhkan.

2) Kemitraan tersebut bervariasi dan dinamis.

3) Kemitraan menjadi efektif melalui jejaring yang memungkinkan multiplikasi.

4) Kemitraan merupakan hubungan baik dan terpelihara.

Kemitraan yang dibangun dalam suatu pelayanan pada dasarnya menggenapi apa yang Tuhan Yesus kehendaki. Tuhan Yesus mendoakan kesatuan para murid-Nya agar "... mereka menjadi satu sama seperti Kita adalah satu" (Yoh 17:20-23), sehingga dunia menjadi percaya kepada Kristus. Selanjutnya kita perhatikan bahwa kemitraan bukanlah sesuatu yang baru, bahkan sudah nampak secara jelas dalam Allah Tritunggal yang melaksanakan misi-Nya yang mulia bagi manusia. Berikut ini beberapa langkah-langkah penting untuk membangun dan membentuk suatu kemitraan:

1. Tahap perkenalan, di mana saling mengetahui ciri khas dan kekuatan masing-masing pihak dan menggumuli bentuk kerjasama dalam doa, sehingga saling mempercayai dan bersama-sama meyakini bahwa kemitraan itu adalah berdasarkan pimpinan Tuhan.

${ }^{25}$ William R. O’Brien, The Power of Collaboration..., 12 
2. Menentukan bersama untuk visi dan tujuan yang akan dicapai, kemudian akan dijadikan rencana terperinci dan dilengkapi dengan perkiraan tentang SDM yang diperlukan, strategi dan sasaran tertentu mengenai apa yang diharapkan tercapai dan bagaimana caranya, serta bagaimana batas waktunya. Dalam kemitraan untuk misi, tentu visi dan tujuan-tujuan ini berhubungan dengan aspek-aspek misi, tentang penginjilan, misi holistik atau lintas budaya. Perlu diingat apabila kerjasamanya dalam program penginjilan, maka harus ada kesepakatan sebelumnya tentang proses pembinaan orang yg baru percaya, dan integrasi mereka ke dalam persekutuan setempat demi menghindari tuduhan dan saling menyalahkan pada waktu pelaksanaan kegiatan bersama itu.

3. Perlu mengembangkan jalur-jalur komunikasi yang jelas serta kesepakatan untuk proses pemantauan dan evaluasi yang akan dijalankan.

4. Dalam pengelolaan sistem keuangan perlu perhatian yang khusus dan disepakati dahulu bersama untuk dijalankan secara terbuka dan transparan serta bertanggung jawab.

5. Adanya aturan dan prosedur khusus yang disepakati dalam menangani kesalah-pahaman, serta untuk mengakhiri atau membarui kemitraan pada waktunya (kalau tujuannya sudah dicapai atau waktunya perlu diperpanjang) atau bila didapati konflik yang tidak dapat diselesaikan.

\section{KESIMPULAN}

Telah disadari bersama bahwa pelayanan misi merupakan pelayanan yang teramat luas, dan dalam memikirkan, merencanakan, mengatur bahkan melaksanakannya dibutuhkan wawasan yang luas pula demi tercapainya Amanat Agung Tuhan Yesus Kristus. Kehadiran gereja sebagai komunitas orang percaya di dunia tidak dapat atau tidak akan mampu jika hanya sebagai pelaksana tunggal dalam melaksanakan mandat Ilahi "menyaksikan Kristus dalam pemberitaan Kabar Baik". Melalui kemitraan dengan pelayananpelayanan misi, penting memulai penataan sistem atau pola kerja yang baik serta terorganisir, hal ini merupakan suatu gerakan yang dinamis dalam melaksanakan Amanat Agung. Kemitraan yang ada perlu sekali dukungan segala pihak karena dengan demikian kemitraan dapat mengembangkan 
pelayanan-pelayanan, bahkan lembaga yang ada sehingga segala program dan sasaran puncak dapat tercapai sesuai kerinduan dalam membangun kemitraan dan pelayanan bersama.

\section{KEPUSTAKAAN}

Ali, Lukman

1999 Kamus Besar Bahasa Indonesia. Jakarta: Balai Pustaka

Barclay, W.

2009 Pemahaman Alkitab Setiap Hari Matius Psl 11-28. Jakarta: BPK Gunung Mulia

Berkhof, Louis

2008 Teologi Sistematika “Doktrin Gereja”. Jakarta: Lembaga Reformed Injili Indonesia

Boice, James Montgomery

2011 Dasar-dasar Iman Kristen. Surabaya: Momentum

Chan, Simon

2010 Spiritual Theology. Yogyakarta: ANDI

Fernando, Ajith

2008 Allah Tritunggal dan Misi. Jakarta: Yayasan Komunikasi Bina

Kasih

Guanga, Caprili

1997 Aku dan Gereja. Malang: Seminari Alkitab Asia Tenggara

Gunawan, Sadikin

2006 Menjadi Orang Kristen Yang Berbeda. Jakarta: Pustaka

Sorgawi

Guthrie, Donald

1996 Teologi Perjanjian Baru 3. Jakarta: BPK Gunung Mulia Johnstone, Patrick \& Jason Mandryk,

2001 Operation World. Carlisle: Paternoster

Kirk, Andrew

1999 What is Mission? (London: Darton, Longman, Todd Liauw, Suhento 
1996 Doktrin Gereja Alkitabiah. Jakarta: Gereja Baptis Independen Alkitabiah AGAPHE

Newman Jr, Barclay M.

2006 Kamus Yunani-Indonesia. Jakarta: BPK Gunung Mulia

Packer, J.I.

2009 Pengijilan dan Kedaulatan Allah. Surabaya: Momentum

Piper, John

2001 Jadikan Sekalian Bangsa Bersukacita. Bandung: Literatur

Baptis Indonesia

Thomas, Norman E.

2001 Teks-teks Klasik tentang Misi dan Kekristenan Sedunia. Jakarta: BPK Gunung Mulia

Tomatala, Yakob

1998 Penginjilan. Malang: Gandum Mas

Tomatala, Yakub

2003 Teologi Misi. Jakarta: YT Leadership Foundation

Willians, Theodore

t.t. Misi dan Jemaat Lokal. Jakarta:OMF 